\title{
Insulin-like Growth Factor-I and Its Binding Proteins in Colostrum Compared to Measures in Serum of Holstein Neonates ${ }^{1}$
}

\author{
A. L. Sparks, ${ }^{\star}$ J. G. Kirkpatrick,† C. S. Chamberlain, ${ }^{\star}$ D. Waldner, ${ }^{\star}$ and L. J. Spicer* \\ ${ }^{*}$ Department of Animal Science and †Department of Veterinary Clinical Sciences, \\ Oklahoma State University, Stillwater, OK 74078
}

\begin{abstract}
Colostral insulin-like growth factor-I (IGF-I) may be beneficial in the development of gastrointestinal tracts of bovine neonates. Thus, the purpose of this study was to examine relationships among concentrations of IGFI and IGF-binding proteins (IGFBP) in colostrum used at two initial feedings and serum concentrations of IGFI, IGFBP, total protein, gamma glutamyltransferase (GGT), and immunoglobulin $\mathrm{G}$ at 0 and $48 \mathrm{~h}$ after birth in Holstein neonates. Calves $(n=22)$ were separated from dams immediately after birth. Blood samples were taken before initial feeding and at $48 \mathrm{~h}$ after birth. Calves were fed $2 \mathrm{~L}$ of colostrum twice and milk replacer thereafter. Linear regression of serum IGF-I at $48 \mathrm{~h}$ and colostral IGF-I revealed a significant positive relationship $\left(R^{2}=0.204\right)$. Serum IGFBP-3 at $48 \mathrm{~h}$ and colostral IGFBP-3 also had a positive relationship $\left(\mathrm{R}^{2}=\right.$ $0.143)$. However, linear regression of colostral IGF-I on the difference in serum IGF-I at 48 and $0 \mathrm{~h}$ was not significant. Calves were assigned to group 1 ( 0 -h serum IGF-I $<10 \mathrm{ng} / \mathrm{ml} ; \mathrm{n}=11)$ or group $2(0$-h serum IGF-I $\geq 10 \mathrm{ng} / \mathrm{ml} ; \mathrm{n}=11$ ) for further analysis. There were no differences in serum IGF-I or IGFBP-2, $-3,-4$, and -5 concentrations at $48 \mathrm{~h}$ between groups 1 and 2 . Correlation coefficients revealed negative relationships of serum IGF-I at $0 \mathrm{~h}$ to the difference between serum IGF$\mathrm{I}$ at 48 and $0 \mathrm{~h}(\mathrm{r}=-0.824)$, as well as birth weight of the calf to the amount of GGT at $48 \mathrm{~h}(\mathrm{r}=-0.604)$. Females had lower birth weights than males, but sex of calf did not affect serum measures. At $0 \mathrm{~h}$, but not $48 \mathrm{~h}$, total serum protein was correlated to serum GGT concentrations $(r=0.573)$. From indirect evidence, $a b-$ sorption of colostral IGF-I and IGFBP-3 into systemic circulation may occur, but relative importance compared to endogenous sources is uncertain.
\end{abstract}

\footnotetext{
Received October 31, 2002.

Accepted January 2, 2003.

Corresponding author: L. J. Spicer; e-mail: igf1Leo@okstate.edu.

${ }^{1}$ Approved for publication by the Director, Oklahoma Agric. Exp. Sta. This research was supported in part under project H-2329 (awarded to L. J. Spicer).
}

(Key words: IGF-I, IGF binding protein, neonatal calf, colostrum)

\begin{abstract}
Abbreviation key: ADU = arbitrary densitometric units, GGT = gamma glutamyltransferase, IGFBP = insulin-like growth factor binding protein(s), IgG = immunoglobulin G.
\end{abstract}

\section{INTRODUCTION}

For maximal survival and subsequent growth rates, the bovine neonate must be fed antibody-rich colostrum (for review see Quigley and Drewry, 1998). Serum gamma glutamyltransferase (GGT) concentration in calves is a reliable measure of passive transfer of colostral immunoglobulins (Perino et al., 1993; Parish et al., 1997). Recent studies suggest other components/factors of colostrum, in addition to immunoglobulins, may be important to neonatal calf health (Quigley and Drewry, 1998). One of these components is likely IGF-I (Baumrucker et al., 1994b; Burrin, 1997; Blum and Baumrucker, 2002). Researchers have determined that IGFI is a key regulator of growth (Davis, 1988; Noguchi, 2000) and reproduction (Spicer and Echternkamp, 1995; Spicer et al., 2000). The nutritional status of an animal has a large impact on the amount of circulating IGF-I; specifically, concentrations of IGF-I in blood are indicators of undernutrition in cattle (Richards et al., 1991, 1995; Bossis et al., 2000), and calorie or protein restriction can inhibit IGF-I secretion (Davis, 1988; McGuire et al., 1992). The development of the small intestine of a calf is largely dependent on protein and energy intake (Buhler et al., 1998). Moreover, IGF-I has been proposed to have a stimulating effect on the small intestine of neonates (Baumrucker et al., 1994b; Burrin, 1997; Blum and Baumrucker, 2002). When IGF-I is added to milk replacer and fed to neonatal calves, gastrointestinal mucosal growth, brush-border enzymes, and intestinal DNA synthesis are stimulated (Baumrucker et al., 1994b). Hammon et al. (2000) concluded that concentrations of IGF-I in bovine neonates mainly are influenced by the intake of colostrum via a nutritional effect. With the high mortality rate in calves, advancing the development of the small intes- 
tine could be extremely beneficial to the development and survival of the calf. However, whether endogenous IGF-I present in colostrum is absorbed by the gut of the bovine neonate is still unresolved. Because IGF binding proteins (IGFBP) can increase the half-life of IGF-I and block its action (Spicer and Echternkamp, 1995), differences in levels of IGFBP in colostrum may influence biological activity of IGF-I within the intestine. The objective of the present study was to determine whether the concentrations of IGF-I and IGFBP in colostrum, fed at the initial two feedings, are associated with concentrations of IGF-I or IGFBP in the systemic circulation of neonatal calves.

\section{MATERIALS AND METHODS}

Twenty-two Holstein dairy calves born at the Oklahoma State University Dairy Cattle Center between September 7, 1998, and November 9, 1998, were used as previously described (Kirkpatrick et al., 2001). Briefly, calves were removed from dams immediately after calving, and a precolostral blood sample was taken $(0 \mathrm{~h})$ from the jugular vein. Blood samples were collected in $5-\mathrm{ml}$ tubes and refrigerated for $24 \mathrm{~h}$. Serum was harvested after centrifugation at $1400 \times g$ for $5 \mathrm{~min}$ and then stored at $-20^{\circ} \mathrm{C}$ until assayed. Each calf received 2 $\mathrm{L}$ of colostrum from a nipple bottle within $6 \mathrm{~h}$ of birth and again approximately $12 \mathrm{~h}$ later. Following the initial two colostrum feedings, calves were fed $2 \mathrm{~L}$ of milk replacer twice daily, at 0800 and $1700 \mathrm{~h}$. For the initial two feedings, colostrum from the dam was used if possible, but a frozen reserve of colostrum was used if colostrum from the dam was unavailable. A sample of colostrum was taken from each of the first two feedings that each calf received and stored at $-20^{\circ} \mathrm{C}$. A second blood sample was collected via jugular venipuncture at $48 \mathrm{~h}$ $( \pm 6 \mathrm{~h})$; serum was harvested as described earlier. Calves were housed in individual calf hutches following birth.

The serum samples from each calf, as well as colostrum samples of the first and second colostrum feedings, were evaluated for IGF-I concentration. Samples were analyzed by radioimmunoassay after acid-ethanol extraction $\left(16 \mathrm{~h}\right.$ at $\left.4^{\circ} \mathrm{C}\right)$ as described previously by Echternkamp et al. (1990). The intraassay coefficient of variation was $9.2 \%$.

Serum and colostrum samples were also analyzed for IGFBP using one-dimensional SDS-PAGE (Stewart et al., 1996; Spicer et al., 2000). Briefly, $8 \mu \mathrm{l}$ of serum or colostrum was mixed with $21 \mu \mathrm{l}$ of nonreducing denaturation buffer $(62.5 \mathrm{mM}$ Tris-HCl, $2 \%$ SDS, $25 \%$ glycerol, and $0.01 \%$ bromphenol blue without mercaptoethanol; Bio-Rad, Hercules, CA). Proteins were denatured at $100^{\circ} \mathrm{C}$ for $3 \mathrm{~min}$ and centrifuged at $4700 \times g$ for 2 min and loaded to wells of $12 \%$ PAGE (15 lanes per gel). All serum samples from three to four calves were run on each gel. Four gels were run at a time in a single electrophoresis chamber. Control lanes included either $25 \mu \mathrm{l}$ of wide-range color marker (MW 6500 to 205,000; Sigma, St. Louis, MO) or a mixture of $4-\mu$ l bovine serum pool and $21 \mu \mathrm{l}$ of the nonreducing denaturation buffer. Gels were run for 18 to $20 \mathrm{~h}$ at constant current and varying voltage, and bands were transferred using nitrocellulose paper (Midwest Scientific, St. Louis, MO) for 2.5 to $3.0 \mathrm{~h}$ and hybridized with ${ }^{125}$ I-IGF-II (about $15,000 \mathrm{cpm} / 0.1 \mathrm{ml}$; total volume $=6 \mathrm{ml}$ ) at $4^{\circ} \mathrm{C}$ for $12 \mathrm{~h}$ in a platform shaker. Nitrocellulose blots were washed with Tris-buffered saline and $0.1 \%$ Tween and then washed again with Tris-buffered saline. Nitrocellulose was dried and placed on X-ray film for $4 \mathrm{~d}$ at $-80^{\circ} \mathrm{C}$. Xray films were developed and bands measured using a densitometer (Molecular Analyst, Bio-Rad). Variations among gels were monitored via running the same bovine serum pool on each gel; IGFBP-2, -3 , and -5 bands were scanned and the resultant arbitrary densitometric units (ADU) for each IGFBP was used to calculate intergel coefficients of variation, which averaged $19.4 \pm 4.5 \%$.

Quantification of IgG in the 48-h serum sample was done by radial immunodiffusion using a commercial kit from Triple J Farms (Bellingham, WA) as previously described (Kirkpatrick et al., 2001). Total serum protein and serum GGT concentrations were measured using Vitros Chemistry Products colorimetric tests according to the manufacture's protocol (Johnson \& Johnson Clinical Diagnostics, Inc., Rochester, NY) as previously described (Kirkpatrick et al., 2001).

\section{Statistical Analyses}

To determine whether concentrations of IGF-I in colostrum during the first two feedings influenced serum IGF-I levels at $48 \mathrm{~h}$ or the change in serum IGF-I between birth and $48 \mathrm{~h}$, linear regressions were performed. Mean colostral IGF-I concentrations were calculated by averaging the IGF-I concentrations in the first two colostrum samples fed to each calf. Serum IGFI at $48 \mathrm{~h}$ and the difference of serum IGF-I at 48 and $0 \mathrm{~h}$ were used as dependent variables, and colostral IGF-I concentration was the independent variable. Similarly, linear regression was performed on concentrations of IGFBP-3 in colostrum and serum IGFBP-3 levels at 0 and $48 \mathrm{~h}$.

To determine whether initial serum IGF-I levels affect the change in serum IGF-I levels between 0 and $48 \mathrm{~h}$ postcalving, data were arranged into two groups based on their precolostral serum IGF-I values. Calves with initial serum containing less than $10 \mathrm{ng} / \mathrm{ml}$ were assigned to group 1 ( $\mathrm{n}=11$; five males and six females), and those with concentrations greater than or equal to 


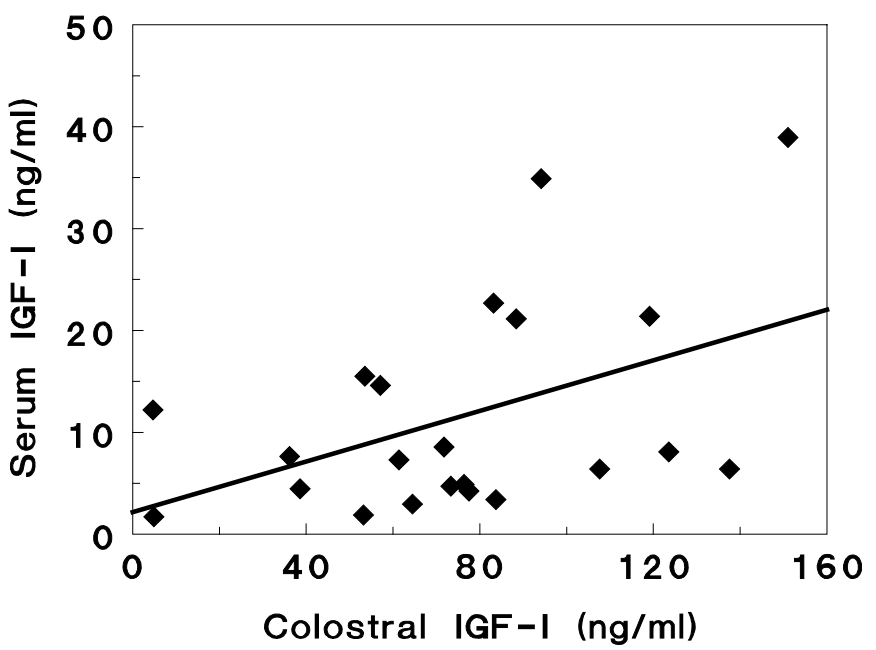

Figure 1. Linear regression of concentrations of serum IGF-I at $48 \mathrm{~h}$ and average colostral IGF-I from the initial two feedings in neonatal dairy calves $\left(\mathrm{y}=0.12 \mathrm{x}+2.18, \mathrm{R}^{2}=0.204, P<0.05\right)$.

$10 \mathrm{ng} / \mathrm{ml}$ were assigned to group $2(\mathrm{n}=11$; five males and six females). These group values were based on the findings of Bossis et al. (2000), which indicated plasma IGF-I concentrations below $10 \mathrm{ng} / \mathrm{ml}$ exist in cattle under severe nutritional restriction. Main effect of group and the interaction between time and group were assessed by ANOVA using PROC MIXED of SAS (1999). In addition, the effect of sex of calf on the serum IGFI difference, serum variables at 0 and $48 \mathrm{~h}$, and birth weight were evaluated by ANOVA using PROC GLM of SAS (1999). Differences were determined using Fisher's protected LSD test (Steel et al., 1997). Significance was declared at $P<0.05$. Trends were noted if $P<0.10$.

Finally, Pearson correlation coefficients were calculated to evaluate relationships among colostral IGF-I, serum IGF-I at 0 and $48 \mathrm{~h}$, the difference between 0 and 48-h serum IGF-I concentration, BW at birth, IgG levels at $48 \mathrm{~h}$, total serum protein at 0 and $48 \mathrm{~h}$, and serum GGT concentration at 0 and $48 \mathrm{~h}$. Data of total serum protein concentrations at 0 and $48 \mathrm{~h}$ and serum IgG concentrations at $48 \mathrm{~h}$ were obtained as previously described in Kirkpatrick et al. (2001).

\section{RESULTS}

Linear regression of serum IGF-I at $48 \mathrm{~h}$ and colostral IGF-I revealed a significant positive relationship $\left(\mathrm{R}^{2}\right.$ $=0.204, P<0.05$; Figure 1). However, simple linear regression of colostral IGF-I and the difference in IGFI concentration in serum between 0 and $48 \mathrm{~h}$ did not show a relationship $\left(\mathrm{R}^{2}=0.003, P>0.25\right)$. Similarly, simple linear regression of colostral IGF-I and serum IGF-I at $0 \mathrm{~h}$ did not show a relationship $\left(\mathrm{R}^{2}=0.096, P\right.$

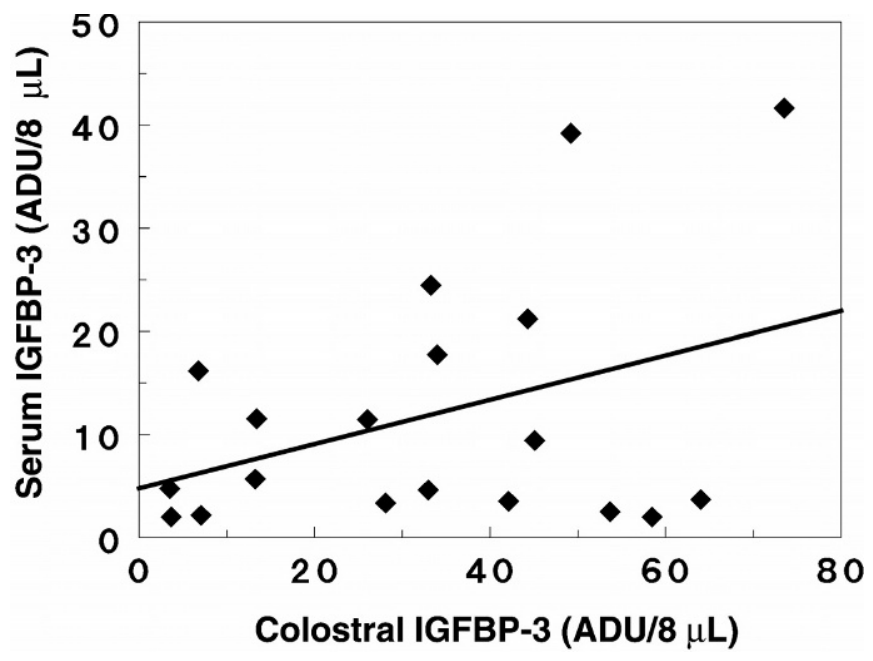

Figure 2. Linear regression of concentrations of IGFBP-3 in serum at $48 \mathrm{~h}$ and average colostral IGFBP-3 from the initial two feedings in neonatal dairy calves $\left(\mathrm{y}=0.22 \mathrm{x}+4.79, \mathrm{R}^{2}=0.143, P<0.10\right.$; ADU $=$ arbitrary densitometric units)

$>0.25)$. Simple linear regression of colostral IGFBP-3 and serum IGFBP-3 at $48 \mathrm{~h}$ revealed a trend for a positive relationship $\left(\mathrm{R}^{2}=0.143, P<0.10\right.$; Figure 2$)$.

When treatment groups were divided according to presuckle serum IGF-I concentration, there was a significant $(P<0.05)$ time $\times$ group interaction. Although group 1 (i.e., calves with initial serum concentrations of IGF-I $<10 \mathrm{ng} / \mathrm{ml})$, had lower $(P<0.01)$ serum IGFI concentrations than group 2 (i.e., calves with initial serum concentrations of IG-I $>10 \mathrm{ng} / \mathrm{ml})$ at $0 \mathrm{~h}$, there were no significant differences $(P>0.25)$ in serum IGFI concentrations between groups at $48 \mathrm{~h}$ (Figure 3 ). In group 1, serum IGF-I concentrations did not increase significantly $(P>0.10)$ between 0 and $48 \mathrm{~h}$, whereas in group 2, serum IGF-I concentrations decreased by $65 \%$ $(P<0.05)$. For serum IGFBP-2, -3 , and -4 , no significant group, time, or time $\times$ group interactions existed (Figure $4)$. However, the time effect was significant $(P<0.05)$ for serum IGFBP-5; serum IGFBP-5 levels decreased $(P<0.05)$ by $43 \%$ between 0 and $48 \mathrm{~h}$ postcalving across groups (Figure 4).

The two major IGFBP detected in colostrum were IGFBP-3 and IGFBP-4, which averaged $34.0 \pm 5.9$ and $0.9 \pm 0.3 \mathrm{ADU} / 8 \mu \mathrm{l}$ of colostrum, respectively (data not shown).

As expected, males had greater $(P<0.05)$ birth weight than female calves (Table 1). However, sex of calf did not affect $(P>0.25)$ concentrations of IGF-I, IgG, total protein, or GGT in serum at 0 or $48 \mathrm{~h}$ (Table 1), nor did sex affect concentrations of serum IGFBP-2, -3, -4, or -5 at 0 or $48 \mathrm{~h}$ (data not shown). 


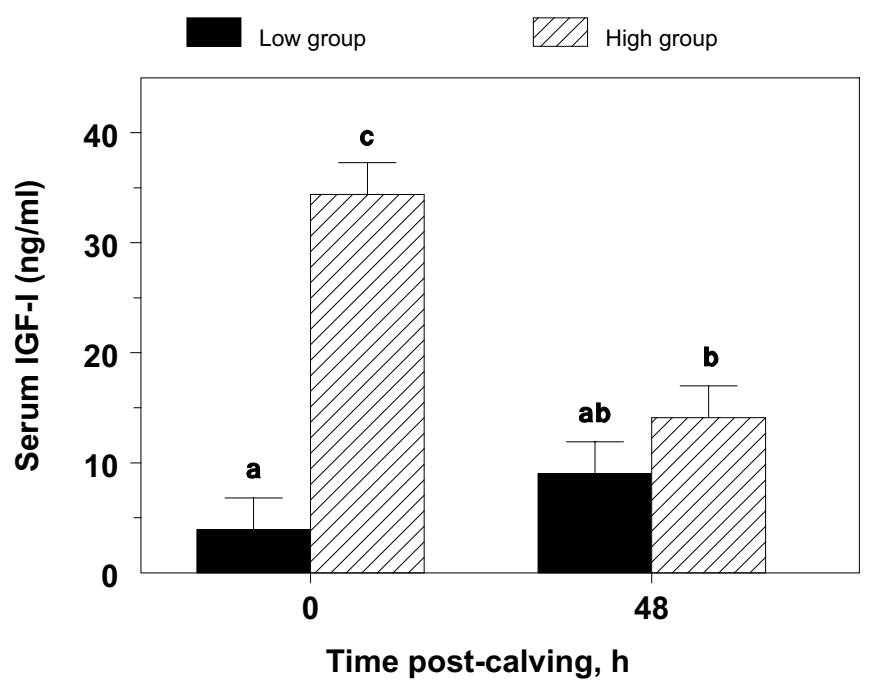

Figure 3. Serum IGF-I concentrations at 0 and $48 \mathrm{~h}$ for calves in the low group $(0 \mathrm{~h} \mathrm{IGF-I}<10 \mathrm{ng} / \mathrm{ml}, \mathrm{n}=11)$ and high group $(0 \mathrm{~h}$ IGF-I $>11 \mathrm{ng} / \mathrm{ml}, \mathrm{n}=11)$. ${ }^{\mathrm{a}, \mathrm{b}}$ Means without a common superscript differ $(P<0.05)$. ${ }^{\mathrm{b}, \mathrm{c}}$ Means without a common superscript differ $(P$ $<0.001)$.

Pearson correlation coefficients are in Table 2. Colostral IGF-I levels were positively correlated $(P<0.05)$ with serum IGF-I at $48 \mathrm{~h}$, whereas serum IgG at $48 \mathrm{~h}$ was positively correlated $(P<0.001)$ with total serum protein at $48 \mathrm{~h}$. Serum GGT at $0 \mathrm{~h}$ was positively correlated $(P<0.05)$ with total serum protein at $0 \mathrm{~h}$. There was a negative correlation $(P<0.001)$ between serum IGF-I at $0 \mathrm{~h}$ and the difference between 0 and $48 \mathrm{~h}$

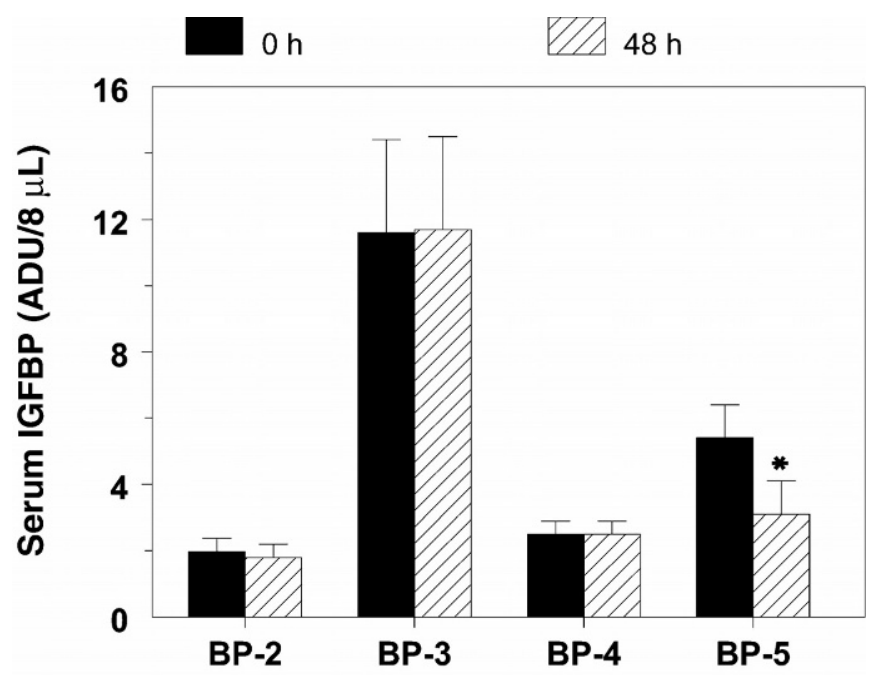

Figure 4. Serum IGFBP concentrations in calves at 0 and $48 \mathrm{~h}$ after birth. Data for calves in the low group $(0 \mathrm{~h}$ IGF-I $<10 \mathrm{ng} / \mathrm{ml})$ and high group $(0 \mathrm{~h}$ IGF-I $>11 \mathrm{ng} / \mathrm{ml})$ were pooled (ADU $=$ arbitrary densitometric units). $* 48$-h mean differs from 0 -h mean $(P<0.05)$. serum IGF-I (Table 2). Serum IGFBP-2, $-3,-4$, and -5 levels were not significantly correlated with serum or colostral IGF-I at 0 or $48 \mathrm{~h}$ (data not shown). Colostral IGF-I was correlated with colostral IGFBP-3 $(r=0.62$, $P<0.01)$ but not colostral IGFBP-4 $(\mathrm{r}=0.33, P>0.10)$.

\section{DISCUSSION}

Results of the present study revealed a positive relationship between colostral IGF-I and IGFBP-3 concentrations and serum concentrations of IGF-I and IGFBP3 , respectively, at $48 \mathrm{~h}$ after birth. Consistent with these results, feeding colostrum at birth results in a higher level of circulating IGF-I at $21 \mathrm{~d}$ of age than in calves fed mature cow milk (Grutter and Blum, 1991). Calves fed milk replacer plus recombinant human IGF-I had greater plasma IGF-I concentrations than those fed either colostrum or milk replacer alone (Skaar et al., 1994). Vacher et al. (1995) catheterized the jejunum and the mesenteric vein draining the jejunum in newborn calves and detected $\left[{ }^{125} \mathrm{I}\right] \mathrm{IGF}-\mathrm{I}$ in the mesenteric vein of these calves after its administration; however, the absorption time of $\left[{ }^{125} \mathrm{I}\right] \mathrm{IGF}-\mathrm{I}$ was short. Other components of colostrum such as IGFBP, not found in milk replacer, may reduce the absorption or stimulating abilities of colostral IGF-I (Baumrucker and Blum, 1994). The present study suggests that some colostral IGFBP3 may also be absorbed by the neonate. Within $24 \mathrm{~h}$ of birth, a neonate's intestine appears to be selectively hyperpermeable to large molecules (Gardner, 1984). Furthermore, intestinal absorption of polypeptides, including IGF-I, has been demonstrated in neonatal rats (Thornburg et al., 1987) and pigs (Xu and Wang, 1996). Thus, IGF-I should be absorbable by the gut within the first $24 \mathrm{~h}$ of life whether it is bound by IGFBP or not. Our study shows that there is much variation in serum IGF-I concentrations in neonates at birth. With such large variation in initial serum IGF-I concentrations, more complex experimental approaches may be required to detect the contribution of colostral IGF-I to serum IGF-I concentrations in bovine neonates.

Orally administered IGF-I stimulates gastrointestinal mucosal growth, numbers of IGF receptors in the intestinal mucosa, and brush-border enzyme activity in 7-d-old calves (Baumrucker et al., 1994b); increases the active ion transport in 5-d-old pigs (Alexander and Carey, 1999); and increases enzyme activity in the jejunum in 14-d-old rats (Young et al., 1990) and newborn rat pups (Ma and Xu, 1997). Moreover, calves fed colostrum for six feedings have increased villus height compared with calves fed colostrum one time or those fed only milk replacer (Buhler et al., 1998). Similarly, systemic administration of IGF-I significantly increased the mucosal thickness in rat pups (Steeb et al., 1997). 
Table 1. Average colostral IGF-I concentration, serum concentrations of IGF-I at 0 and $48 \mathrm{~h}$ postcalving, difference between $0 \mathrm{~h}$ and $48 \mathrm{~h}$ in serum IGF-I concentrations, serum IgG at $48 \mathrm{~h}$, total serum protein at 0 and $48 \mathrm{~h}$, serum GGT at 0 and $48 \mathrm{~h}$, and birth weight of male and female Holstein calves.

\begin{tabular}{|c|c|c|c|c|}
\hline Variable & Mean & Male & Female & SEM \\
\hline No. of Calves & & 10 & 12 & \\
\hline Colostral IGF-I ${ }^{\mathrm{a}}, \mathrm{ng} / \mathrm{ml}$ & 75.51 & 69.61 & 80.42 & 11.58 \\
\hline Serum IGF-I at $0 \mathrm{~h}, \mathrm{ng} / \mathrm{ml}$ & 19.21 & 19.46 & 18.99 & 5.57 \\
\hline Serum IGF-I at $48 \mathrm{~h}, \mathrm{ng} / \mathrm{ml}$ & 11.55 & 10.36 & 12.54 & 3.20 \\
\hline Serum IGF-I change $(0-48 \mathrm{~h}), \mathrm{ng} / \mathrm{ml}$ & -7.663 & -9.11 & -6.46 & 5.21 \\
\hline Serum IgG at $48 \mathrm{~h}, \mathrm{ng} / \mathrm{ml}$ & 1942.0 & 2013.7 & 1882.7 & 292.6 \\
\hline BW at birth*, kg & 38.93 & 42.23 & 36.17 & $4.51^{*}$ \\
\hline Total serum protein at $0 \mathrm{~h}, \mathrm{~g} / \mathrm{dl}$ & 4.44 & 4.60 & 4.32 & 0.13 \\
\hline Total serum protein at $48 \mathrm{~h}, \mathrm{~g} / \mathrm{dl}$ & 6.07 & 6.15 & 6.00 & 0.24 \\
\hline Serum GGT at $0 \mathrm{~h}, \mathrm{U} / \mathrm{L}$ & 24.67 & 23.78 & 25.33 & 3.66 \\
\hline Serum GGT at $48 \mathrm{~h}, \mathrm{U} / \mathrm{L}$ & 1233.0 & 1079.3 & 1361.2 & 249.1 \\
\hline
\end{tabular}

${ }^{\text {a }}$ Mean concentration of IGF-I in colostrum at first and second feeding.

*Male vs. female, $P<0.05$.

Collectively, these studies indicate that orally ingested IGF-I stimulates changes in small intestinal villus size and function in several species of neonates including calves. Whether endogenous IGF-I found in colostrum acts in this manner is not clear.

The negative correlation between serum IGF-I at 0 $\mathrm{h}$ and the difference between serum IGF-I at 0 and 48 $\mathrm{h}$ was because calves born with higher serum IGF-I (i.e., group 2) had a significant decrease in serum IGFI concentration between birth and $48 \mathrm{~h}$, whereas calves born with low serum IGF-I (i.e., group 1) had no significant change in serum IGF-I during the same interval. Although absorption of IGF-I from the colostrum into the systemic circulation is a possibility, the current results indicate that the concentration of serum IGFI at birth is important in determining serum IGF-I concentrations at $48 \mathrm{~h}$. Consistent with the findings of the present study, Hammon et al. (2000) reported that plasma levels of IGF-I decrease between 0 and $48 \mathrm{~h}$ after birth and that these IGF-I levels during the first $24 \mathrm{~h}$ of life are significantly influenced by how soon after birth the first colostrum is fed. Unfortunately, serum collections at $24 \mathrm{~h}$ or earlier were not performed in the present study to allow more precise monitoring of neonatal changes in serum IGF-I. Previously, calves fed colostrum had sixfold greater systemic concentrations of IGF-I than calves fed milk replacer during the first week of life (Hammon and Blum, 1997). Perhaps colostrum protects IGF-I from intestinal degradation as has been reported for pigs (Shen and $\mathrm{Xu}, 2000$ ). Because birth weight was not significantly correlated with serum IGF-I at either 0 or $48 \mathrm{~h}$, it is unlikely that birth weight accounts for differences in serum IGF-I levels among bovine neonates.

In the present study, four IGFBP were detected in serum of neonatal calves, whereas only IGFBP-3 and 4 were detected in colostrum of their dams. Similar to previous studies (Skaar et al., 1991), IGFBP-3 was the dominant IGFBP found in colostrum. There was a $43 \%$ decrease in serum IGFBP-5 levels between 0 and $48 \mathrm{~h}$, whereas serum IGFBP-2, -3 , and -4 did not change. Similarly, plasma IGFBP-2 and -3 levels in calves did

Table 2. Correlation coefficients among concentrations of IGF-I in colostrum (Colo) and serum at 0 and 48 $\mathrm{h}$, the difference (Diff) in serum IGF-I at 48 vs. $0 \mathrm{~h}$, serum IgG concentrations at $48 \mathrm{~h}$, BW at birth, total serum protein concentrations at 0 and $48 \mathrm{~h}$, and serum GGT concentrations at 0 and $48 \mathrm{~h}$ in Holstein calves $(\mathrm{n}=22)$.

\begin{tabular}{|c|c|c|c|c|c|c|c|c|c|}
\hline & $\begin{array}{l}0 \mathrm{~h} \\
\text { IGF-I }\end{array}$ & $\begin{array}{l}48 \mathrm{~h} \\
\text { IGF-I }\end{array}$ & $\begin{array}{l}\text { Diff } \\
48-0 \mathrm{~h}\end{array}$ & IgG & BW & $\begin{array}{l}\text { Protein } \\
0 \mathrm{~h}\end{array}$ & $\begin{array}{l}\text { Protein } \\
48 \mathrm{~h}\end{array}$ & $\begin{array}{l}\text { GGT } \\
0 \mathrm{~h}\end{array}$ & $\begin{array}{l}\text { GGT } \\
48 \mathrm{~h}\end{array}$ \\
\hline Colo & 0.310 & $0.452^{*}$ & 0.131 & 0.131 & -0.106 & -0.0009 & 0.161 & 0.179 & 0.306 \\
\hline 0 h IGF-I & ........ & 0.391 & $-0.824^{* *}$ & 0.083 & 0.225 & -0.224 & 0.007 & 0.154 & -0.022 \\
\hline 48 h IGF-I & & .......... & 0.199 & -0.330 & -0.009 & 0.010 & 0.103 & 0.196 & -0.283 \\
\hline Diff $48-0 \mathrm{~h}$ & - & & .......... & -0.291 & -0.246 & 0.168 & -0.259 & -0.201 & -0.151 \\
\hline IgG & & & & .......... & 0.115 & -0.092 & $0.880 * *$ & 0.263 & 0.190 \\
\hline BW & & & & & .......... & 0.009 & 0.103 & 0.196 & $-0.604 *$ \\
\hline Protein $0 \mathrm{~h}$ & & & & & & $\ldots \ldots \ldots$ & 0.043 & $0.573^{*}$ & 0.335 \\
\hline Protein $48 \mathrm{~h}$ & & & & & & & ......... & 0.347 & 0.203 \\
\hline
\end{tabular}

$* P<0.05$.

$* * P<0.001$. 
not change between d 1 and 3 after birth (Hammon et al., 2000). However, levels of plasma IGFBP-2 increase and levels of plasma IGFBP-3 decrease between 1 and $7 \mathrm{~d}$ of age in calves (Skaar et al., 1994). The dominant binding protein in neonatal blood at $1 \mathrm{~d}$ of age in the present and previous study was IGFBP-3 (Skaar et al., 1994), but by $7 \mathrm{~d}$ of age, IGFBP-2 was reported to be the dominant IGFBP in serum of calves (Skaar et al., 1994). Although the present study is first to report a decrease in serum IGFBP-5 in neonates during their first $2 \mathrm{~d}$ of life, its physiologic relevance remains to be elucidated.

Plasma protein levels have been shown to increase within the first week of life (Hammon et al., 2000) and with the consumption of colostrum (Rauprich et al., 2000), and results from the present study are consistent with this finding. The present study also indicated a significant positive relationship between total serum protein and GGT at $0 \mathrm{~h}$; therefore, endogenous GGT may have contributed to the normal homeostatic levels of serum protein in the calf before colostrum feeding. The significant positive correlation between serum IgG at $48 \mathrm{~h}$ and total serum protein at $48 \mathrm{~h}$ suggests that IgG derived from ingestion of colostrum contributes significantly to serum protein levels in neonatal calves. Total serum protein includes both the Ig and the nonIg serum proteins (Parish et al., 1997). Perino et al. (1993) and Parish et al. (1997) both determined that serum GGT level is a more useful test for passive transfer of colostral Ig than total protein due to the lack of influence of hydration. Calves are born with low to negligible GGT activity, and thus the bulk of neonatal serum GGT is colostral derived (Parish et al., 1997). Hammon and Blum (1998) also found GGT activity significantly increased after colostrum intake. Similarly, serum GGT levels of calves in the present study increased between 0 and $48 \mathrm{~h}$ after birth. The negative correlation between the birth weight and GGT levels at $48 \mathrm{~h}$ is likely due to the fact that the calves in this study were fed a constant volume of colostrum, and thus larger calves received less colostrum per kilogram of BW than smaller calves. Serum GGT, total serum protein, and serum IgG levels were correlated in other studies (Perino et al., 1993) but not in the present study. These discrepancies may be due to the fact that blood samples were taken at $48 \mathrm{~h}$ in the present study, whereas Perino et al. (1993) collected blood samples at $24 \mathrm{~h}$, and Hammon and Blum (1998) collected blood at $1,2,4$, and $7 \mathrm{~h}$ after feeding colostrum. Concentrations of GGT peak within $4 \mathrm{~h}$ after its oral ingestion and remain constant through $32 \mathrm{~h}$ and slowly decrease during the subsequent $8 \mathrm{~d}$ (Baumrucker et al., 1994a). Thus, in the present study, blood samples may have been collected after the decline in serum GGT had already begun.

In the present study, male calves weighed $16.7 \%$ more than female calves. Similarly, Kertz et al. (1997) found male calves were $8.5 \%$ heavier than females. To our knowledge, this study is the first to show a lack of sex effect on serum IGF-I and the various IGFBP concentrations in neonatal calves. Because the age of the animal has a significant impact on the amount of IGF-I, IGFBP, and steroids in the systemic circulation (Roberts et al., 1990; Davis et al., 1995; Clapper et al., 2000), it is likely that neonates would not be old enough to exhibit a sex effect on IGF-I or IGFBP concentrations at $48 \mathrm{~h}$ postcalving. Lack of effect of sex on serum protein and IgG levels in calves of the present study agrees with a previous report (Perino et al., 1995).

No significant correlation between birth weight and serum IGF-I concentration across sexes was found in the present study; this correlation, when conducted within sex, was also not significant (data not shown). In contrast, Breier et al. (1988) found a significant correlation between IGF-I concentration and birth weight ( $\mathrm{r}$ $=0.78, \mathrm{n}=15$ ) in newborn male Friesian calves. Moreover, Holland et al. (1997) found fetal BW to be strongly correlated with serum IGF-I concentrations. Reasons for the discrepancy between the present and previous studies is unclear. Whether breed type and(or) nutritional status of the dam affects neonatal IGF-I levels at birth and thereby influences the correlation between birth weight and serum IGF-I concentration will require further study.

\section{CONCLUSIONS}

Results of the present study provide indirect evidence for absorption of IGF-I and IGFBP-3 from colostrum into systemic circulation via a positive relationship between colostral IGF-I and IGFBP-3 and serum IGF-I and IGFBP-3 concentrations at $48 \mathrm{~h}$. However, there was also a negative correlation between serum IGF-I and the difference between serum IGF-I at 0 and $48 \mathrm{~h}$ because calves born with higher initial serum IGF-I concentration experienced a decrease in serum IGF-I between birth and $48 \mathrm{~h}$ of life. Further research is needed to determine the effects of other milk components and initial serum IGF-I on the transfer of IGF-I and IGFBP-3 from colostrum to the neonate, as well as to determine factors that may influence the rate of IGFI decline in the neonate.

\section{ACKNOWLEDGMENTS}

The authors thank the National Hormone and Pituitary for supplying the IGF-I antibody (UB2-495), Mon- 
santo Company for supplying the recombinant bovine IGF-II used for ligand blotting, David Jones and Kelli Payne for assistance with sample collection and animal care, Dustin Allen for technical assistance, and the OSU Recombinant DNA/Protein Resource Facility for the use of its molecular imager and scanning densitometer.

\section{REFERENCES}

Alexander, A. N., and H. V. Carey. 1999. Oral IGF-I enhances nutrient and electrolyte absorption in neonatal piglet intestine. Am. J. Physiol. 277:G619-G625.

Baumrucker, C. R., and J. W. Blum. 1994. Effects of dietary recombinant human insulin-like growth factor-I on concentrations of hormones and growth factors in the blood of newborn calves. J. Endocrinol. 140:15-21.

Baumrucker, C. R., M. H. Green, and J. W. Blum. 1994a. Effects of dietary rhIGF-I in neonatal calves on the appearance of glucose, insulin, D-xylose, globulins and gamma-glutamyl transferase in blood. Domest. Anim. Endocrinol. 11:393-403.

Baumrucker, C. R., D. L. Hadsell, and J. W. Blum. 1994b. Effects of dietary insulin-like growth factor I on growth and insulin-like growth factor receptors in neonatal calf intestine. J. Anim. Sci. 72:428-433.

Blum, J. W., and C. R. Baumrucker. 2002. Colostral and milk insulinlike growth factors and related substances: Mammary gland and neonatal (intestinal and systemic) targets. Domest. Anim. Endocrinol. 23:101-110.

Bossis, I., R. P. Wettemann, S. D. Welty, J. Vizcarra, and L. J. Spicer. 2000. Nutritionally induced anovulation in beef heifers: Ovarian and endocrine function during realimentation and resumption of ovulation. Biol. Reprod. 62:1436-1444.

Breier, B. H., P. D. Gluckman, and J. J. Bass. 1988. Plasma concentrations of insulin-like growth factor-I and insulin in the infant calf: Ontogeny and influence of altered nutrition. J. Endocrinol. 119:43-50.

Buhler, C., H. Hammon, G. L. Rossi, and J. W. Blum. 1998. Small intestinal morphology in eight-day-old calves fed colostrum for different durations or only milk replacer and treated with LongR3-insulin-like growth factor I and growth hormone. J. Anim. Sci. 76:758-765.

Burrin, D. G. 1997. Is milk-borne insulin-like growth factor-I essential for neonatal development? J. Nutr. 127:975S-979S.

Clapper, J. A., T. M. Clark, and L. A. Rempel. 2000. Serum concentrations of IGF-I, estradiol-17 $\beta$, testosterone, and relative amounts of IGF binding proteins (IGFBP) in growing boars, barrows, and gilts. J. Anim. Sci. 78:2581-2588.

Davis, M. E., M. D. Bishop, N. H. Park, and R. C. M. Simmen. 1995. Divergent selection for blood serum insulin-like growth factor I concentration in beef cattle: I. Nongenetic effects. J. Anim. Sci. 73:1927-1932.

Davis, S. L. 1988. Recent concepts in regulation of growth by GH and IGF. J. Anim. Sci. 66(Suppl. 3):84-97.

Echternkamp, S. E., L. J. Spicer, K. E. Gregory, S. F. Canning, and J. M. Hammond. 1990. Concentrations of insulin-like growth factor-I in blood and ovarian follicular fluid of cattle selected for twins. Biol. Reprod. 43:8-14.

Gardner, M. L. G. 1984. Intestinal assimilation of intact peptides and proteins from the diet-A neglected field? Biol. Rev. 59:289-331.

Grutter, R., and J. Blum. 1991. Insulin-like growth factor I in neonatal calves fed colostrum or whole milk and injected with growth hormone. J. Anim. Physiol. Anim. Nutr. 66:231-239.

Hammon, H., and J. W. Blum. 1997. The somatotropic axis in neonatal calves can be modulated by nutrition, growth hormone, and LongR3-IGF-I. Am. J. Physiol. 273:E130-E138.

Hammon, H. M., and J. W. Blum. 1998. Metabolic and endocrine traits of neonatal calves are influenced by feeding colostrum for different durations or only milk replacer. J. Nutr. 128:624-632.
Hammon, H. M., I. A. Zanker, and J. W. Blum. 2000. Delayed colostrum feeding affects IGF-I and insulin plasma concentrations in neonatal calves. J. Dairy Sci. 83:85-92.

Holland, M. D., K. L. Hossner, S. E. Williams, C. R. Wallace, G. D. Niswender, and K. G. Odde. 1997. Serum concentrations of insulin-like growth factors and placental lactogen during gestation in cattle. I. Fetal profiles. Domest. Anim. Endocrinol. 14:231-239.

Kertz, A. F., L. F. Ruetzel, B. A. Barton, and R. L. Ely. 1997. Body weight, body condition score, and wither height of prepartum Holstein cows and birth weight and sex of calves by parity: A data base and summary. J. Dairy Sci. 80:525-529.

Kirkpatrick, J., R. W. Fulton, L. J. Burge, W. R. Dubois, and M. Payton. 2001. Passively transferred immunity in newborn calves, rate of antibody decay, and effect of subsequent vaccination with modified live virus vaccine. Bovine Pract. 35:47-55.

Ma, L., and R. J. Xu. 1997. Oral insulin-like growth factor-I stimulates intestinal enzyme maturation in newborn rats. Life Sci. 61:51-58.

McGuire, M. A., J. L. Vicini, D. E. Bauman, and J. J. Veenhuizen. 1992. Insulin-like growth factors and binding proteins in ruminants and their nutritional regulation. J. Anim. Sci. 70:29012910.

Noguchi, T. 2000. Protein nutrition and insulin-like growth factor system. Br. J. Nutr. 84 (Suppl. 2):S241-S244.

Parish, S. M., J. W. Tyler, T. E. Besser, C. C. Gay, and D. Krytenberg. 1997. Prediction of serum IgG1 concentrations in Holstein calves using serum gamma glutamyltransferase activity. J. Vet. Int. Med. 11:344-347.

Perino, L. J., R. L. Sutherland, and N. E. Woollen. 1993. Serum $\gamma-$ glutamyltransferase activity and protein concentration at birth and after suckling in calves with adequate and inadequate passive transfer of immunoglobulin G. Am. J. Vet. Res. 54:56-59.

Perino, L. J., T. E. Wittum, and G. S. Ross. 1995. Effects of various risk factors on plasma protein and serum immunoglobulin concentrations of calves at postpartum hours 10 and 24. Am. J. Vet. Res. 56:1144-1148.

Quigley, J. D., III, and J. J. Drewry. 1998. Nutrient and immunity transfer from cow to calf pre- and postcalving. J. Dairy Sci. 81:2779-2790.

Rauprich, A. B. E., H. M. Hammon, and J. W. Blum. 2000. Influence of feeding different amounts of first colostrum on metabolic, endocrine, and health status and on growth performance in neonatal calves. J. Anim. Sci. 78:896-908.

Richards, M. W., L. J. Spicer, and R. P. Wettemann. 1995. Influence of diet and ambient temperature on bovine serum insulin-like growth factor-I and thyroxine: Relationships with non-esterified fatty acids, glucose, insulin, luteinizing hormone and progesterone. Anim. Reprod. Sci. 37:267-279.

Richards, M. W., R. P. Wettemann, L. J. Spicer, and G. L. Morgan. 1991. Nutritional anestrus in beef cows: Effects of body condition and ovariectomy on serum luteinizing hormone and insulin-like growth factor-I. Biol. Reprod. 44:961-966.

Roberts, C. A., S. N. McCutcheon, H. T. Blair, P. D. Gluckman, and B. H. Breier. 1990. Developmental patterns of plasma insulinlike growth factor-I concentrations in sheep. Domest. Anim. Endocrinol. 7:457-464.

SAS User's Guide: Statistics, Version 8. Edition. 1999. SAS Inst., Inc., Cary, NC.

Shen, W. H. and R. J. Xu. 2000. Stability of insulin-like growth factor I in the gastrointestinal lumen in neonatal pigs. J. Pediatr. Gastroenterol. Nutr. 30:299-304.

Skaar, T. C., C. R. Baumrucker, D. R. Deaver, and J. W. Blum. 1994 Diet effects and ontogeny of alterations of circulating insulin-like growth factor binding proteins in newborn dairy calves. J. Anim. Sci. 72:421-427.

Skaar, T. C., J. R. Vega, S. N. Pyke, and C. R. Baumrucker. 1991. Changes in insulin-like growth factor-binding proteins in bovine mammary secretions associated with pregnancy and parturition. J. Endocrinol. 131:127-133.

Spicer, L. J., P. Alvarez, T. M. Prado, G. L. Morgan, and T. D. Hamilton. 2000. Effects of intraovarian infusion of insulin-like growth 
factor-I on ovarian follicular function in cattle. Domest. Anim. Endocrinol. 18:265-278.

Spicer, L. J., and S. E. Echternkamp. 1995. The ovarian insulin and insulin-like growth factor system with an emphasis on domestic animals. Domest. Anim. Endocrinol. 12:223-245.

Steeb, C. B., C. A. Shoubridge, D. R.Tivey, and L. C. Read. 1997. Systemic infusion of IGF-I or LR ${ }^{3}$ IGF-I stimulates visceral organ growth and proliferation of gut tissues in suckling rats. Am. J. Physiol. 272:G522-G533.

Steel, R. G. D., J. H. Torrie, and D. A. Dickey. 1997. Principles and Procedures of Statistics: A Biometrical Approach. 3rd ed. McGraw-Hill, New York, NY.

Stewart, R. E., L. J. Spicer, T. D. Hamilton, B. E. Keefer, L. J. Dawson, G. L. Morgan, and S. E. Echternkamp. 1996. Levels of insulinlike growth factor (IGF) binding proteins, luteinizing hormone and IGF-I receptors, and steroids in dominant follicles during the first follicular wave in cattle exhibiting regular estrous cycles. Endocrinology 137:2842-2850.

Thornburg, W., R. K. Rao, L. M. Matrisian, B. E. Magun, and O. Koldovsky. 1987. Effect of maturation on gastrointestinal absorption of epidermal growth factor in rats. Am. J. Physiol. 253:G68-G71.

Vacher, P. Y., G. Bestetti, and J. W. Blum. 1995. Insulin-like growth factor-I absorption in the jejunum of neonatal calves. Biol. Neonate 68:354-367.

Xu, R. J., and T. Wang. 1996. Gastrointestinal absorption of insulinlike growth factor-I in neonatal pigs. J. Pediatr. Gastroenterol. Nutr. 23:430-437.

Young, G. P., T. M. Taranto, H. A. Jonas, A. J. Cox, A. Hogg, and G. A. Werther. 1990. Insulin-like growth factors and the developing and mature rat small intestine: Receptors and biological actions. Digestion 46(Suppl. 2):240-252. 